\title{
Fra stud.med. til legestudent
}

\author{
Titlene studentene bruker om seg selv er blitt mindre formelle med årene. Har stud.med., medisinsk student \\ og medisinerstudent gått ut på dato?
}

Min far var stud.med. Han studerte medisin i Oslo i en tid da studentene var kledd i dress og slips og titulerte sine lærere professor Monrad-Krohn og prosektor Brodal. Det var stas å være medisinsk student og naturlig å kalle seg stud.med. Det var status å være akademiker og bære svart studenterlue på 17. mai.

Da jeg studerte medisin i Oslo i 1970årene, var det ikke like naturlig å kalle seg stud.med. Dette var studentopprørets tid, og mange akademikere ville solidarisere seg med arbeiderklassen. Enkelte leger foretrakk å kalle seg helsearbeider fremfor lege. Var man student, fikk det holde med student. For dem som ville markere hvilket fag man studerte, ble det til at man kalte seg medisinerstudent. Stud.med. var blitt for stivbeint og gammeldags.

Da studentene i 1986 organiserte seg i en forening under Den norske legeforening, ble navnet Norsk medisinerstudentforening. Skrivemåten «medisiner-» som første ledd $i$ et sammensatt ord er nokså konservativ på samme måte som «studenter-» er det. Sammensatte ord som studenterlue, studenterhjem og studentereksamen (1) vil nok oppfattes av de fleste som nokså gammelmodige. Nå skriver vi heller studentby, studentopprør og studentopptak (2). Ved andre

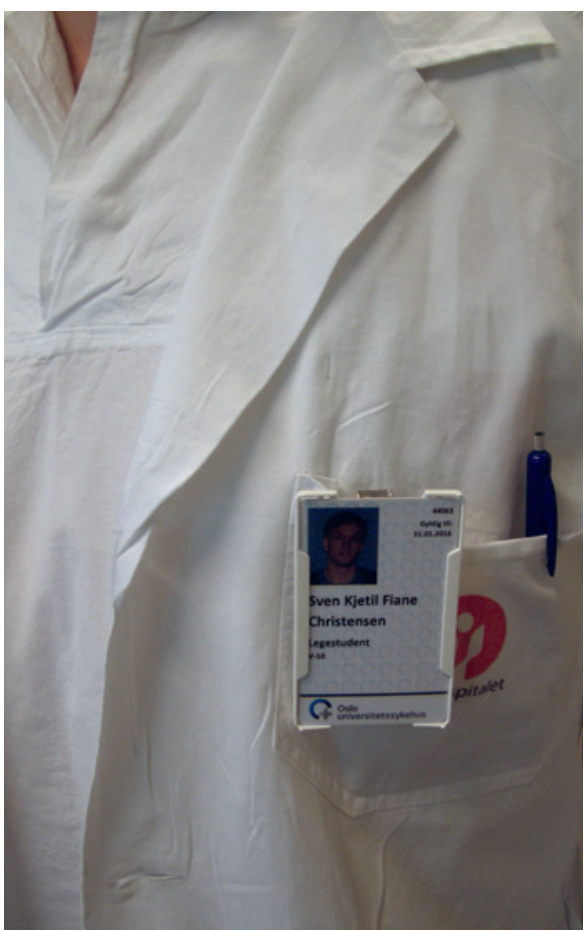

Stud.med. Sven Kjetil Fiane Christensen er legestudent og tillitsvalgt i Norsk medisinstudentforening. som inntil 1993 het Norsk medisinerstudentforening. Foto Petter Gjersvik fakulteter blir studentene kalt jusstudenter og teologistudenter - ikke juriststudenter eller teologstudenter $(3,4)$. Med andre ord: fag + student.

Foreningsnavnet ble endret til Norsk medisinstudentforening i 1993. Begrunnelsen skal ha vært et ønske om modernisering (Bjørg Bakke, leder i Norsk medisinstudentforening, personlig meddelelse).

\section{Navneskiltene}

Som lærer på Rikshospitalet i et klinisk fag forsøker jeg så godt det lar seg gjøre å bli kjent med studentene. Da må jeg se på navneskiltene hva de heter. Det slo meg at de færreste brukte betegnelser som stud.med., medisinerstudent, medisinstudent eller student på navneskiltet. Det sto Legestudent på de fleste. Denne betegnelsen ble også brukt i tittelen på en bok fra 2002 om medisinstudiet i Oslo (5). Var dette uttrykk for en språklig utvikling i studentmassen?

For å få vite mer om dette sendte jeg en e-post til alle studentene på et kull for å kartlegge valg av tittel på navneskiltet og begrunnelse for valget. Av svarene jeg fikk, fremkom det at teksten var bestemt av det administrative personalet på hvert sykehus, og at praksisen varierte - både på samme studiested og fra studiested til studiested. På Rikshospitalet og Ullevål sykehus var Legestudent nesten enerådende. På Akershus universitetssykehus hadde noen fått Medisinerstudent eller Medisinstudent på navneskiltet sitt. På Aker sykehus forekom også Med.student, Med.stud., Stud.med. og Student og leietaker (!).

Av dem som ga uttrykk for hvilken betegnelse de selv ville ha valgt dersom de var blitt gitt muligheten, ville de fleste valgt legestudent, dernest medisinstudent. Mange mente at legestudent var lettest å forstå for pasientene. Noen fortalte at ordet medisinstudent av enkelte pasienter blir oppfattet som en betegnelse på en som studerer farmasi, ettersom medisin ofte brukes synonymt med legemiddel. Andre ville unngå betegnelsen medisinstudent, fordi det nå finnes kortere studier i medisin, bl.a. ved en privat høyskole i Oslo og på Universitetet i Tromsø $(6,7)$. Greit å vise at man ikke går der, men at man skal bli lege.

\section{Legestudent}

Hvilken betegnelse bør man så bruke? Ordbøkene gir varierende råd. I Tanums store rettskrivningsordbok står kun oppført medisinstudent (3), mens i Store Norske Ordbok står kun medisinerstudent (4). Tidsskriftets egen ordliste følger Tanums ordbok (8). Substantivet medisiner kan ifølge ordbøkene brukes om både leger og medisinstudenter $(3,4,9)$.

Jeg mener at de fleste av de omtalte betegnelsene fortsatt er aktuelle. Det er omstendighetene som er avgjørende for ordvalget.

På sykehus og legekontorer der studentene har klinisk praksis, er nok legestudent det som passer best - det er lett å forstå for pasientene og vanskelig å misforstå. Medisinstudent er kanskje mest passende i akademiske sammenhenger - det fremhever faget (medisin) fremfor det kommende yrket (lege). I studentkretser kan man gjerne kalle seg medisiner. Medisinsk student, medisinerstudent og stud.med. har nok i stor grad gått ut på dato. Stud.med. kan fortsatt være aktuelt i svært formelle sammenhenger, men slike er det jo ikke mange igjen av.

\section{Petter Gjersvik}

petter.gjersvik@medisin.uio.no

Institutt for klinisk medisin

Oslo universitetssykehus, Rikshospitalet

Jeg takker studentene som besvarte e-posten og Erlend Hem for nyttige innspill og god hjelp.

Petter Gjersvik (f. 1952) er førsteamanuensis og undervisningsleder i dermatologi og venerologi ved Oslo universitetssykehus, Rikshospitalet, og medisinsk redaktør i Tidsskriftet.

Litteratur

1. Knudsen T Sommerfelt A Norsk riksmålsordbok. Bd. 2 (skjønn-åvokster). Oslo: Aschehoug, 1957 2278-9.

2. Noreng H. Norsk riksmålsordbok. Bd. 6 (hohenstaufer-å-yl. Oslo: Kunnskapsforlaget, 1995: 2341.

3. Wangensteen B. red. Tanums store rettskrivningsordbok. 9. utg. Oslo: Kunnskapsforlaget, 2005: 523.

4. Guttu T. red. Aschehoug og Gyldendals store norske ordbok: riksmål og moderat bokmål. 2. utg. Oslo: Kunnskapsforlaget, 2005: 474-5

5. Larsen $\emptyset$. Legestudent i hovedstaden. Oslo: Gyldendal Akademisk, 2002.

6. Atlantis Medisinske Høgskole. www.amh.no/ (31.5.2012)

7. Universitetet i Troms $\varnothing$. For studies $\varnothing$ kere. http:// uit.no/for-studiesokere?ar $=2012 \&$ semester $=H$ (31.5.2012)

8. Ordliste M. Forfatterveiledningen. Tidsskrift for Den norske legeforening. http://tidsskriftet.no/ Innhold/Forfatterveiledningen/Spraak/Ordliste/M (29.5.2012)

9. Bokmålsordboka. www.nob-ordbok.uio.no/perl/ ordbok.cgi?OPP=medisiner (29.5.2012). 